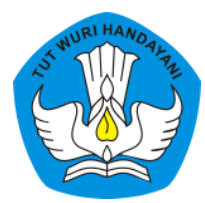

Page: 677-692

\title{
Peningkatan Kreativitas dan Literasi Digital Peserta Didik Melalui Metode Resitasi dalam Pembuatan Film Pendek Sejarah
}

\author{
Siti Khoimah \\ Sekolah Menengah Pertama Islam Al Abidin Surakarta Jawa Tengah \\ Contributor Email: sitikhoimah452@gmail.com
}

Article Url: http://ojsdikdas.kemdikbud.go.id/index.php/didaktika/article/view/138

\begin{abstract}
The Industrial Revolution 4.0 requires the world of education to participate in developing a knowledgeable society with the characteristics of having 21st century skills that are creative and have digital literacy capabilities to be able to compete globally. Social studies learning is identical with rote learning and difficult for students to understand, so teachers are expected to continue to innovate so that learning becomes more active and dynamic. The purpose of this study was to determine whether the recitation method in making historical short films can increase students' creativity and digital literacy. The subjects in this study were students of class VIII-A at Al Abidin Islamic Middle School Surakarta in the Academic Year 2017/2018 Semester 2 as many as 35 people. The instrument used to assess creativity is to use the rubric of creativity assessment, observation, and self-assessment of students. Digital literacy assessment uses the digital literacy assessment rubric and student self-assessment. The results showed that the recitation method in making historical short films was able to increase students' creativity and digital literacy. In the first cycle of research, the creativity of students obtained an average value of 72.5. This figure shows that students are already in the creative category. Digital literacy of students obtained an average value of 62.5, also included in the category quite well. In the second cycle research the average value of students' creativity increased to 81.3 in the very creative category, and the digital literacy of students increased to 75.0, with a good category. Observation results show that the recitation method in making historical short films can improve students' creativity and digital literacy.
\end{abstract}

Keywords: Recitation Method; Historical Short Film; Creativity; Digital Literacy 


\begin{abstract}
Abstrak
Revolusi Industri 4.0 menuntut dunia pendidikan untuk turut mengembangkan masyarakat berpengetahuan dengan ciri memiliki keterampilan abad 21 yakni kreatif serta memiliki kemampuan literasi digital agar mampu bersaing secara global. Pembelajaran IPS identik dengan hafalan dan sulit dipahami peserta didik, sehingga pendidik diharapkan dapat terus berinovasi agar pembelajaran menjadi lebih aktif dan dinamis. Tujuan penelitian ini adalah untuk mengetahui apakah metode resitasi dalam pembuatan film pendek sejarah dapat meningkatkan kreativitas dan literasi digital peserta didik. Subjek dalam penelitian ini adalah peserta didik kelas VIII-A di SMP Islam Al Abidin Surakarta pada Tahun Pelajaran 2017/2018 Semester 2 sebanyak 35 orang. Instrumen yang digunakan untuk menilai kreativitas yakni menggunakan rubrik penilaian kreativitas, observasi, dan penilaian diri peserta didik. Penilaian literasi digital menggunakan rubrik penilaian literasi digital dan penilaian diri peserta didik. Hasil penelitian menunjukkan bahwa metode resitasi dalam pembuatan film pendek sejarah mampu meningkatkan kreativitas dan literasi digital peserta didik. Pada penelitian siklus I, kreatifitas peserta didik diperoleh nilai ratarata sebesar 72,5. Angka tersebut menunjukkan bahwa peserta didik sudah berada pada kategori kreatif. Literasi digital peserta didik diperoleh nilai rata-rata 62,5, juga masuk pada kategori cukup baik. Pada penelitian siklus II nilai rata-rata kreativitas peserta didik meningkat menjadi 81,3 dengan kategori sangat kreatif, dan literasi digital peserta didik meningkat menjadi 75,0, dengan kategori baik. Hasil observasi menunjukkan bahwa metode resitasi dalam pembuatan film pendek sejarah mampu meningkatkan kreatifitas dan literasi digital peserta didik.
\end{abstract}

Kata Kunci: $\quad$ Metode Resitasi; Film Pendek Sejarah; Kreativitas; Literasi Digital

\title{
A. Pendahuluan
}

Maraknya trend digital saat ini atau dalam dunia pendidikan yang ditandai dengan semakin luasnya jangkauan penggunaan internet untuk pembelajaran, menyebabkan terjadinya pergeseran pada masyarakat Indonesia dari masyarakat offline menuju masyarakat online. Perkembangan dunia saat ini yang telah masuk pada Revolusi Industri 4.0, dimana segala sesuatu bertumpu pada cyber-physical system, menuntut semua pelaku dibidang pendidikan mampu menyesuaikan diri pada setiap perkembangan zaman. Masuknya Revolusi Industri 4.0 dalam bidang pendidikan turut mengubah peran pendidik dari "penyaji" materi pelajaran menjadi fasilitator pembelajaran bagi peserta didiknya. Pembelajaran bukan lagi mengacu pada teacher centered (berpusat pada pendidik) melainkan sudah bergeser menjadi 
student centered (berpusat pada peserta didik). Pada pembelajaran yang dirancang pendidik inilah diharapkan peserta didik mampu menguasai literasi digital agar semakin mampu bersaing dengan tuntutan zaman yang semakin pesat di bidang teknologi digital sekarang ini.

"Pendidikan adalah sarana penting dan strategis dalam membangun masyarakat berpengetahuan yang memiliki keterampilan abad 21 antara lain: (1) melek teknologi dan media; (2) melakukan komunikasi efektif; (3) mampu berpikir kritis; (4) problem solving; dan (5) berkolaborasi" (Anonim, 2018:9). Dari uraian di atas, mengindikasikan bahwa pembelajaran abad 21 mengharuskan peserta didik memiliki kecakapan literasi digital dan literasi ICT. Oleh karena itu, kecakapan mengenali, menggunakan secara teknis, dan memanfaatkan pada kegiatan pembelajaran merupakan aspek yang harus dimiliki peserta didik pada abad 21.

Pembelajaran IPS di sekolah merupakan salah satu mata pelajaran yang kurang disukai peserta didik. Alasannya, peserta didik menganggap bahwa pelajaran ini cenderung hafalan dan sulit dipahami. Salah satu contoh materi yang menjadi momok peserta didik dalam pelajaran IPS adalah materi sejarah yang berisi kejadian pada masa lampau yang tidak dapat dirasakan atau dialami langsung pada masa sekarang sehingga materi ini cenderung kurang disukai peserta didik karena dianggap bersifat hafalan, abstrak dan sulit dipahami. Apalagi jika penyampaian pendidik masih bersifat konvensional dan hanya berpusat pada pendidik (teacher center) sehingga peserta didik hanya sebagai pendengar dan pasrah menerima apa yang disampaikan pendidik. Hal ini akan berdampak pada kondisi peserta didik mudah bosan, tidak tertarik dengan pelajaran, mudah sekali mengantuk sehingga materi sulit sekali diterima dan yang paling parah adalah hilangnya kreativitas peserta didik dalam pembelajaran.

Berdasarkan hasil observasi penulis dan pengisian angket di kelas VIII A SMP Islam Al Abidin Surakarta T.P. 2017/2018 hampir 88,5 \% peserta didik mempunyai gadget pribadi baik itu berupa HP maupun laptop atau notebook. Fasilitas yang mereka punyai ini hanya terbatas pada penggunaan pembelajaran TIK saja sehingga tidak diimbangi dengan 
optimalisasi pemanfaatan gadget dalam pembelajaran di kelas. Hal ini menyebabkan tingkat kreativitas peserta didik sangat rendah yang ditandai dengan (1) minimnya peserta didik yang mengajukan pertanyaan dan menanggapi, (2) kurang bersemangat dalam pembelajaran, (3) cenderung pasif dalam memberikan ide.

Sebagian besar peserta didik hampir sudah mempunyai gadged berkamera, biasanya mereka menggunakan gadged mereka untuk selfie dan diupload di sosmed pribadi atau hanya untuk sekedar koleksi foto pribadi yang sifatnya kurang bermanfaat sehingga kemampuan literasi digital juga rendah. Selain itu, tingginya penggunaan media social seperti Instagram, Facebook, Twitter, You Tube oleh peserta didik merupakan tanda era digital sudah masuk dalam kehidupan sehari-hari mereka. Hal ini dipandang sebagai potensi yang bisa dikembangkan oleh pendidik untuk meningkatkan kreativitas dan literasi digital sehingga kualitas proses pembelajaran dapat diperbaiki dengan memanfaatkan media yang setiap hari dianggap peserta didik sebagai "refresing" yang sifatnya lebih kekinian.

Aktifitas nge-vlog dan kemampuan editing video yang sudah dimiliki peserta didik ini, bisa dikembangkan menjadi metode resitasi (penugasan) dalam pembelajaran IPS kelas VIII semester 2 yaitu pada materi perlawanan terhadap kolonialisme dan imperialisme (sebelum tahun 1908), guna meningkatkan kreativitas dan literasi digital peserta didik agar semakin siap menghadapi tantangan abad 21 dan revolusi industri 4.0.

Dari uraian latar belakang diatas, peneliti berupaya untuk mewujudkan terjadinya peningkatan kreativitas dan literasi digital peserta didik melalui metode resitasi pembuatan film pendek sejarah. Slameto (1991:115) mengungkapkan bahwa :

"metode resitasi adalah cara menyampaikan pembelajaran dengan memberikan tugas kepada peserta didik untuk dikerjakan di luar jadwal sekolah dalam jangka waktu tertentu dan hasilnya harus dipertanggungjawabkan kepada pendidik".

Sedangkan, pengertian film pendek menurut durasinya adalah film yang durasinya antara 1-30 menit masuk dalam golongan film 
pendek (Latif dan Utud, 2013:24). Melalui metode resitasi pembuatan film pendek sejarah diharapkan mampu meningkatkan kreativitas dan literasi digital peserta didik.

Kreativitas merupakan sebuah kecakapan dalam menyusun sebuah perpaduan yang baru, berdasarkan data atau informasi yang ada (Nana, 2004:58). Data atau informasi tersebut akan memunculkan suatu jawaban dengan berbagai permasalahan yang ada dengan menekankan pada kualitas atau mutu, ketepatgunaan, dan keragaman jawaban. Dengan kata lain, dapat disimpulkan bahwa kreativitas akan mencerminkan kelancaran, keluwesan, dan orisinilitas seseorang dalam berpikir dan mengelaborasi sebuah gagasan. Aspek kreativitas ini dapat dijabarkan sebagai berikut :

a. Orisinal (Orisinalitas), merupakan kemampuan memunculkan alternatif pernyataan atau jawaban yang tidak biasa pada umumnya.

b. Luwes (flexibility), merupakan kemampuan memberikan ide yang mampu mengubah sebuah cara atau pendekatan.

c. Lancar (fluency), merupakan sebuah kemampuan untuk memunculkan sebuah gagasan atau ide yang relevan.

d. Rinci (Elaborasi), merupakan kemampuan mengembangkan dan memperinci sebuah ide.

Kecapakan abad 21 lainnya yang ingin dicapai dalam penelitian tindakan kelas ini adalah meningkatnya literasi digital. Menurut Bawden (2001:218) mengemukakan bahwa literasi digital adalah : "sebuah keterampilan teknis dalam mengakses, merangkai, memahami, dan menyebarluaskan informasi berjejaring atau digital". Dengan kecakapan ini diharapkan peserta mampu bersaing dalam tantangan abad 21.

Berdasarkan uraian diatas, rumusan masalah dari penelitian ini adalah apakah metode resitasi dalam pembuatan film pendek sejarah mampu meningkatkan kreativitas dan literasi digital peserta didik. Dari rumusan tersebut, maka tujuan penelitian tindakan kelas ini antara lain untuk mengetahui apakah metode resitasi dala pembuatan film pendek sejarah 
mampu meningkatkan kreativitas dan literasi digital peserta didik, khususnya di sekolah yang diteliti.

\section{B. Metode}

Metode penelitian menggunakan Penelitian Tindakan Kelas (PTK) yang terdiri dari 4 komponen yaitu perencanaan, pelaksanaan, observasi dan refleksi. PTK dilakukan dalam 2 siklus, setiap siklus dilaksanakan dalam 2 kali pertemuan. Siklus pertama merupakan pelaksanaan dari rencana yang sudah disusun peneliti. Sedangkan siklus kedua merupakan perbaikan dari hasil observasi dan refleksi dari siklus pertama. Subjek penelitian adalah kelas VIIIA SMP Islam Al Abidin Surakarta Tahun Pelajaran 2017/208 Semester 2 sebanyak 35 peserta didik. Instrumen yang digunakan untuk menilai kreativitas dengan menggunakan rubrik penilaian kreativitas, observasi, dan penilaian diri peserta didik. Untuk menilai literasi digital digunakan rubrik penilaian literasi digital dan penilaian diri peserta didik. Hasil penelitian kemudian dianalisis menggunakan metode deskriptif kualitatif.

\section{Hasil dan Pembahasan}

Penelitian ini diawali dengan melakukan perencanaan tindakan dengan menyusun rencana pembelajaran menggunakan metode resitasi pembuatan film pendek sejarah. Langkah awal tindakan adalah dengan memberikan tugas proyek kepada peserta didik untuk membuat sebuah produk film sejarah dari materi IPS "Perlawanan terhadap kolonialisme dan imperialisme (sebelum tahun 1908)". Pada tahap pelaksanaan siklus I diawali dengan diskusi peserta didik pada perteman pertama untuk membahas tentang berdiskusi untuk mencari lokasi shooting, alat dan bahan yang dibutuhkan serta pembagian tugas seperti pemain, sutradara, penulis naskah, cameramen dan editor video. Selanjutnya adalah tahap resitasi pembuatan film pendek dengan memberi rentang waktu 3 minggu untuk proses shooting sampai editing. Produk film pendek yang dibuat peserta didik kemudian diukur untuk mengetahui peningkatan kreativitas dan literasi peserta didik. Adapun hasil penelitian adalah sebagai berikut : 


\section{Siklus I}

\section{a. Hasil Penilaian Kreativitas Peserta Didik Siklus I}

Data hasil penilaian kreativitas peserta didik dinilai berdasarkan hasil karya film pendek yang dibuat oleh masing-masing kelompok berikut ini :

\section{1) Rubrik Penilaian Kreativitas Peserta Didik Siklus I}

Tabel 1. Hasil Penilaian Kreativitas Film Pendek Sejarah Siklus I

\begin{tabular}{|c|c|c|c|c|c|c|c|c|}
\hline \multirow{2}{*}{ No } & \multirow{2}{*}{ Kelompok } & \multicolumn{4}{|c|}{ Aspek yang dinilai } & \multirow{2}{*}{$\begin{array}{l}\text { Total } \\
\text { Skor }\end{array}$} & \multirow{2}{*}{ Nilai } & \multirow{2}{*}{ Kriteria } \\
\hline & & Orisinal & Luwes & Lancar & Rinci & & & \\
\hline 1 & $\begin{array}{l}\text { Kelompok } 1 \text { (Perang } \\
\text { Aceh) }\end{array}$ & 3 & 2 & 3 & 4 & 12 & 75 & K \\
\hline 2 & $\begin{array}{l}\text { Kelompok } 2 \text { (Perang } \\
\text { maluku) }\end{array}$ & 3 & 2 & 3 & 2 & 10 & 63 & K \\
\hline 3 & $\begin{array}{l}\text { Kelompok } 3 \text { (Perang } \\
\text { Padri 1) }\end{array}$ & 3 & 3 & 4 & 4 & 14 & 88 & SK \\
\hline 4 & $\begin{array}{l}\text { Kelompok } 4 \text { (Perang } \\
\text { Diponegoro) }\end{array}$ & 3 & 3 & 4 & 4 & 14 & 88 & SK \\
\hline 5 & $\begin{array}{l}\text { Kelompok } 5 \text { (Perang } \\
\text { Jagaraga) }\end{array}$ & 3 & 2 & 2 & 1 & 8 & 50 & CK \\
\hline \multicolumn{2}{|c|}{ Jumlah } & 15 & 12 & 16 & 15 & & & \\
\hline \multicolumn{2}{|c|}{ Nilai } & 75 & 60 & 80 & 75 & & & \\
\hline \multicolumn{2}{|c|}{ Kriteria } & $\mathrm{K}$ & CK & SK & $\mathrm{K}$ & & & \\
\hline
\end{tabular}

Keterangan :

CK (Cukup Kreatif), K (Kreatif), SK (sangat Kreatif)

\section{Penilaian :}

Skor Total : 16

Nilai : $\frac{\text { Skor yang diperoleh }}{\text { Skor total }} \times 100$

Skala Kriteria :

81 - 100 : Sangat Kreatif

$61-80$ : Kreatif

41 - 60 : Cukup Kreatif

$21-40$ : Kurang Kreatif

0 - 20 : tidak kreatif

Sumber : Arikunto, dkk (2007:18)

\section{2) Hasil Observasi Kreativitas Peserta Didik Siklus I}

Observasi dilakukan ketika peserta didik melakukan diisi dalam merencanakan pembuatan film pendek sejarah, dengan hasil sebagai berikut : 
Tabel 2. Hasil Observasi Kreativitas Peserta Didik Siklus I

\begin{tabular}{|c|c|c|c|c|c|c|c|c|}
\hline \multirow{2}{*}{$\begin{array}{l}\mathbf{N} \\
\mathbf{0}\end{array}$} & \multirow{2}{*}{ Kreativitas Belajar Peserta Didik } & \multicolumn{5}{|c|}{ Kelompok } & \multirow{2}{*}{$\begin{array}{c}\text { Banyaknya } \\
\text { peserta }\end{array}$} & \multirow{2}{*}{$\%$} \\
\hline & & 1 & 2 & 3 & 4 & 5 & & \\
\hline 1 & Memberikan gagasan atau usulan yang baru & 3 & 3 & 6 & 6 & 4 & 22 & 63 \\
\hline 2 & Mencatat dengan bahasa sendiri & 2 & 2 & 3 & 2 & 1 & 10 & 29 \\
\hline 3 & Membahas hal-hal yang diketahui dan tidak diketahui & 4 & 5 & 7 & 6 & 3 & 25 & 71 \\
\hline 4 & Menanggapi pendapat teman & 6 & 5 & 6 & 4 & 3 & 24 & 69 \\
\hline 5 & Memiliki alternative dalam menyelesaikan masalah & 2 & 2 & 3 & 2 & 2 & 11 & 31 \\
\hline 6 & Lancar dalammengemukakanide/pendapat & 3 & 3 & 5 & 5 & 3 & 19 & 54 \\
\hline 7 & Dapat berpendapat dengan baik & 2 & 3 & 4 & 4 & 1 & 14 & 40 \\
\hline 8 & Hasil diskusi kerja kelompok disusun secara rapi & 1 & 1 & 2 & 1 & 1 & 6 & 17 \\
\hline 9 & Lengkap dan runtut dalam memaparkan hasil diskusi & 3 & 2 & 5 & 4 & 2 & 16 & 46 \\
\hline 10 & Mengajukan pertanyaan & 5 & 4 & 6 & 5 & 2 & 22 & 63 \\
\hline \multicolumn{7}{|c|}{ Jumlah } & & 483 \\
\hline \multicolumn{7}{|c|}{ Rata-rata } & & 48,3 \\
\hline
\end{tabular}

\section{3) Hasil Penilaian Diri Peserta Didik Siklus I}

Penilaian diri peserta didik berisi pertanyaan yang berkaitan dengan indikator kreativitas sekaligus literasi digital. Adapun datanya sebagai berikut :

Tabel 3. Hasil Penilaian Diri Peserta Didik Siklus I

\begin{tabular}{|c|c|c|c|}
\hline No & Pertanyaan & Ya (\%) & Tidak (\%) \\
\hline \multicolumn{4}{|c|}{ Kreativitas Peserta Didik } \\
\hline 1 & $\begin{array}{l}\text { Apakah kamu ikut andil dalam memberikan ide/ pendapat } \\
\text { dalam pembuatan film pendek sejarah merupakan ide tunggalmu? }\end{array}$ & 71,4 & 28,6 \\
\hline 2 & Apakah film pendek sejarah merupakan hasil sendiri ? & 100,0 & - \\
\hline 3 & $\begin{array}{l}\text { Apakah kamu mengumpulkan bahan rujukan terlebih dahulu } \\
\text { sebelum membuat film pendek sejarah? }\end{array}$ & 75,0 & 25,0 \\
\hline 4 & $\begin{array}{l}\text { Apakah ide film pendek sejarah yang kalian buat terisnpirasi } \\
\text { dari karya orang lain? }\end{array}$ & 40,0 & 60,0 \\
\hline 5 & $\begin{array}{l}\text { Apakah kamu turut serta menyumbangkan ide pembuatan } \\
\text { film pendek sejarah yang dihasilkan dalam kelompokmu? }\end{array}$ & 82,8 & 17,2 \\
\hline 6 & $\begin{array}{l}\text { Apakah kamu sudah melaksanakan perencanaan terlebih } \\
\text { dahulu sebelum membuat film pendek sejarah? }\end{array}$ & 80,0 & 20,0 \\
\hline 7 & Apakah film yang dibuat sesuai dengan rancangan perencanaan? & 40,0 & 60,0 \\
\hline 8 & $\begin{array}{l}\text { Apakah menurutmu pesan atau informasi yang ada dalam } \\
\text { film sudah benar? }\end{array}$ & 71,42 & 28,58 \\
\hline 9 & $\begin{array}{l}\text { Apakah menurutmu pesan atau informasi yang ada dalam } \\
\text { film mudah dipahami? }\end{array}$ & 40,0 & 60,0 \\
\hline 10 & $\begin{array}{l}\text { Apakah sudah ada pembagian tugas yang jelas dalam } \\
\text { membuat film pendek sejarah? }\end{array}$ & 91,4 & 8,6 \\
\hline 11 & Apakah kamu merencanakan perlengkapan yang akan digunakan? & 71,4 & 28,6 \\
\hline \multicolumn{4}{|c|}{ Literasi Digital Peserta Didik } \\
\hline 12 & Apakah kamu kesulitan dalam mengakses internet? & 42,8 & 57,2 \\
\hline 13 & Apakah kamu memiliki minimal 1 gadget sendiri di rumah ? & 88,5 & 11,5 \\
\hline 14 & $\begin{array}{l}\text { Apakah kamu bisa mengoperasikan minimal program microsoft } \\
\text { pada gadget dengan baik? }\end{array}$ & 94,2 & 6,8 \\
\hline 15 & Apakah kamu bisa melakkan editing video? & 88,5 & 11,5 \\
\hline 16 & Apakah menurutmu film yang kalian buat sudah mampu & 77,1 & 22,9 \\
\hline
\end{tabular}




\begin{tabular}{|c|l|c|c|}
\hline & dikatakan bermanfaat? & & \\
\hline 17 & $\begin{array}{l}\text { Apakah kamu menggunakan media sosial untuk menyebarkan } \\
\text { film yang dibuat? }\end{array}$ & 40,0 & 60,0 \\
\hline
\end{tabular}

\section{b. Hasil Penilaian Literasi Digital Peserta Didik Siklus I}

1) Rubrik Penilaian Literasi Digital Peserta Didik Siklus I

Penilaian literasi digital peserta didik menggunakan 4 indikator dari bawden (2001:218) yaitu : (1) mengakses, (2) merangkai, (3) memahami, dan (4) menyebarkan informasi. Adapun hasil penilaian literasi digital peserta didik dapat dilihat pada tabel berikut ini :

Tabel 4. Hasil Penilaian Literasi Digital Peserta Didik Siklus I

\begin{tabular}{|c|c|c|c|c|c|c|c|c|}
\hline \multirow[b]{2}{*}{ No } & \multirow[b]{2}{*}{ Kelompok } & \multicolumn{4}{|c|}{ Aspek yang dinilai } & \multirow{2}{*}{$\begin{array}{l}\text { Total } \\
\text { Skor }\end{array}$} & \multirow[b]{2}{*}{ Nilai } & \multirow{2}{*}{$\begin{array}{c}\text { Krite } \\
\text { ria }\end{array}$} \\
\hline & & $\begin{array}{l}\text { Meng } \\
\text { akses }\end{array}$ & $\begin{array}{c}\text { Meran } \\
\text { gkai }\end{array}$ & $\begin{array}{l}\text { Mema } \\
\text { hami }\end{array}$ & $\begin{array}{l}\text { Menyebarkan } \\
\text { Informasi }\end{array}$ & & & \\
\hline 1 & $\begin{array}{l}\text { Kelompok } 1 \\
\text { (Perang Aceh) }\end{array}$ & 1 & 4 & 1 & 2 & 8 & 50 & CB \\
\hline 2 & $\begin{array}{l}\text { Kelompok } 2 \\
\text { (Perang maluku) }\end{array}$ & 2 & 4 & 1 & 2 & 9 & 56 & CB \\
\hline 3 & $\begin{array}{l}\text { Kelompok } 3 \\
\text { (Perang Padri 1) }\end{array}$ & 4 & 4 & 3 & 4 & 15 & 94 & SB \\
\hline 4 & $\begin{array}{l}\text { Kelompok } 4 \\
\text { (PerangDiponegoro) }\end{array}$ & 2 & 3 & 3 & 2 & 10 & 63 & B \\
\hline 5 & $\begin{array}{l}\text { Kelompok } 5 \\
\text { (PerangJagaraga) }\end{array}$ & 2 & 2 & 1 & 3 & 8 & 50 & CB \\
\hline \multicolumn{2}{|c|}{ Jumlah } & 11 & 17 & 9 & 13 & & & \\
\hline \multicolumn{2}{|c|}{ Nilai } & 55 & 85 & 45 & 65 & & & \\
\hline \multicolumn{2}{|c|}{ Kriteria } & $\mathrm{CB}$ & SB & $\mathrm{CB}$ & $\mathrm{B}$ & & & \\
\hline
\end{tabular}

Keterangan : CB (Cukup Baik), B (Baik), SB (Sangat Baik)

\section{Penilaian :}

Skor Total : 16

Nilai : $\frac{\text { Skor yang diperoleh }}{\text { Skor total }} \times 100$

Skala kategori:

$81-100$ : Sangat Baik

$61-80$ : Baik

$41-60$ : Cukup Baik

$21-40$ : Kurang Baik

0 - 20 : Tidak Baik

Sumber : Arikunto, dkk (2007:18) 


\section{2) Hasil Penilaian Diri Peserta Didik}

Untuk melihat hasil penilaian diri peserta didik dalam literasi digital dapat dilihat pada tabel 4 , table tersebut berisi pertanyaan dari 2 indikator sekaligus yaitu kreativitas dan literasi digital peserta didik.

\section{Siklus II}

a. Penilaian Kreativitas Peserta Didik Siklus II

1) Rubrik Penilaian Kreativitas Peserta Didik Siklus II

Tabel 5. Hasil Penilaian Kreativitas Film Pendek Sejarah Siklus II

\begin{tabular}{|c|c|c|c|c|c|c|c|c|}
\hline \multirow{2}{*}{ No } & \multirow{2}{*}{ Kelompok } & \multicolumn{4}{|c|}{ Aspek yang dinilai } & \multirow{2}{*}{$\begin{array}{l}\text { Total } \\
\text { Skor }\end{array}$} & \multirow{2}{*}{ Nilai } & \multirow{2}{*}{ Kriteria } \\
\hline & & Orisinal & Luwes & Lancar & Rinci & & & \\
\hline 1 & $\begin{array}{l}\text { Kelompok1 (Perang } \\
\text { Aceh) }\end{array}$ & 4 & 3 & 4 & 4 & 15 & 94 & SK \\
\hline 2 & $\begin{array}{l}\text { Kelompok } 2 \text { (Perang } \\
\text { maluku) }\end{array}$ & 3 & 3 & 3 & 3 & 12 & 75 & $\mathrm{~K}$ \\
\hline 3 & $\begin{array}{l}\text { Kelompok } 3 \text { (Perang } \\
\text { Padri 1) }\end{array}$ & 4 & 3 & 4 & 4 & 15 & 94 & SK \\
\hline 4 & $\begin{array}{l}\text { Kelompok } 4 \text { (Perang } \\
\text { Diponegoro) }\end{array}$ & 3 & 3 & 4 & 4 & 14 & 88 & SK \\
\hline 5 & $\begin{array}{l}\text { Kelompok } 5 \text { (Perang } \\
\text { Jagaraga) }\end{array}$ & 3 & 3 & 2 & 1 & 9 & 56 & CK \\
\hline \multicolumn{2}{|c|}{ Jumlah } & 17 & 15 & 17 & 16 & & & \\
\hline \multicolumn{2}{|c|}{ Nilai } & 85 & 75 & 85 & 80 & & & \\
\hline \multicolumn{2}{|c|}{ Kriteria } & $\mathrm{K}$ & $\mathrm{K}$ & $\mathrm{K}$ & $\mathrm{K}$ & & & \\
\hline
\end{tabular}

\section{2) Hasil Observasi Kreativitas Peserta Didik Siklus II}

Tabel 6. Hasil Observasi Kreativitas Peserta Didik Siklus

\begin{tabular}{|c|c|c|c|c|c|c|c|c|}
\hline \multirow{2}{*}{ No } & \multirow{2}{*}{ Kreativitas Belajar Peserta Didik } & \multicolumn{5}{|c|}{ Kelompok } & \multirow{2}{*}{$\begin{array}{l}\text { Banyaknya } \\
\text { peserta }\end{array}$} & \multirow{2}{*}{$\%$} \\
\hline & & 1 & 2 & 3 & 4 & 5 & & \\
\hline 1 & Memberikan gagasan atau usulan yang baru & 5 & 4 & 7 & 6 & 4 & 26 & 74 \\
\hline 2 & Mencatat dengan bahasa sendiri & 6 & 3 & 4 & 5 & 4 & 22 & 63 \\
\hline 3 & $\begin{array}{l}\text { Membahas hal-hal yang diketahui dan tidak } \\
\text { diketahui }\end{array}$ & 5 & 6 & 7 & 6 & 5 & 29 & 83 \\
\hline 4 & Menanggapi pendapat teman & 6 & 5 & 6 & 5 & 5 & 27 & 77 \\
\hline 5 & Memiliki alternative dalam menyelesaikan masalah & 5 & 3 & 5 & 4 & 3 & 20 & 57 \\
\hline 6 & Lancar dalam mengemukakan ide/pendapat & 4 & 3 & 6 & 5 & 3 & 21 & 60 \\
\hline 7 & Dapat berpendapat dengan baik & 4 & 3 & 4 & 4 & 2 & 17 & 49 \\
\hline 8 & Hasil diskusi kerja kelompok disusun secara rapi & 2 & 2 & 2 & 2 & 2 & 10 & 29 \\
\hline 9 & $\begin{array}{l}\text { Lengkap dan runtut dalam memaparkan hasil } \\
\text { diskusi }\end{array}$ & 3 & 2 & 5 & 4 & 2 & 16 & 46 \\
\hline 10 & Mengajukan pertanyaan & 5 & 5 & 6 & 7 & 4 & 27 & 77 \\
\hline \multicolumn{7}{|c|}{ Jumlah } & & 614 \\
\hline \multicolumn{7}{|c|}{ Rata-rata } & & 61.4 \\
\hline
\end{tabular}




\section{3) Hasil Penilaian Diri Peserta Didik Siklus II}

Tabel 7. Hasil Penilaian Diri Peserta Didik Siklus II

\begin{tabular}{|c|l|c|c|}
\hline No & \multicolumn{1}{|c|}{ Pertanyaan } & Ya (\%) & Tidak (\%) \\
\hline Kreativitas Peserta Didik & & \\
\hline 1 & $\begin{array}{l}\text { Apakah kamu ikut andil dalam memberikan ide/pendapat dalam } \\
\text { pembuatan film pendek sejarah merupakan ide tunggalmu? }\end{array}$ & 71,4 & 28,6 \\
\hline 2 & Apakah film pendek sejarah merupakan hasil sendiri? & 100,0 & - \\
\hline 3 & $\begin{array}{l}\text { Apakah kamu mengumpulkan bahan rujukan terlebih dahulu } \\
\text { sebelum membuat film pendek sejarah? }\end{array}$ & 75,0 & 25,0 \\
\hline 4 & $\begin{array}{l}\text { Apakah ide film pendek sejarah yang kalian buat terisnpirasi dari } \\
\text { karya orang lain? }\end{array}$ & 40,0 & 60,0 \\
\hline 5 & $\begin{array}{l}\text { Apakah kamu turut serta menyumbangkan ide pembuatan film } \\
\text { pendek sejarah yang dihasilkan dalam kelompokmu? }\end{array}$ & 82,8 & 17,2 \\
\hline 6 & $\begin{array}{l}\text { Apakah kamu sudah melaksanakan perencanaan terlebih dahulu } \\
\text { sebelum membuat film pendek sejarah? }\end{array}$ & 80,0 & 20,0 \\
\hline 7 & Apakah film yang dibuat sesuai dengan rancangan perencanaan? & 58,3 & 41,7 \\
\hline 8 & $\begin{array}{l}\text { Apakah menurutmu pesan atau informasi yang ada dalam film } \\
\text { sudah benar? }\end{array}$ & 61,7 & 38,3 \\
\hline 9 & $\begin{array}{l}\text { Apakah menurutmu pesan atau informasi yang ada dalam film } \\
\text { mudah dipahami? }\end{array}$ & 57,1 & 42,9 \\
\hline 10 & $\begin{array}{l}\text { Apakah sudah ada pembagian tugas yang jelas dalam membuat } \\
\text { film pendek sejarah? }\end{array}$ & 91,4 & 8,6 \\
\hline 11 & Apakah kamu merencanakan perlengkapan yang akan digunakan? & 71,4 & 28,6 \\
\hline Literasi Digital Peserta Didik & & 42,8 \\
\hline 12 & Apakah kamu kesulitan dalam mengakses internet? & 88,5 & 11,5 \\
\hline 13 & Apakah kamu memiliki minimal 1 gadget sendiri di rumah ? & 94,2 & 6,8 \\
\hline 14 & $\begin{array}{l}\text { Apakah kamu bisa mengoperasikan minimal program microsoft } \\
\text { pada gadget dengan baik? }\end{array}$ & 88,5 & 11,5 \\
\hline 15 & Apakah kamu bisa melakkan editing video? & 77,1 & 22,9 \\
\hline 16 & $\begin{array}{l}\text { Apakah menurutmu film yang kalian buat sudah mampu dikatakan } \\
\text { bermanfaat? }\end{array}$ & 80,0 & 20,0 \\
\hline 17 & $\begin{array}{l}\text { Apakah kamu menggunakan media sosial untuk menyebarkan film } \\
\text { yang dibuat? }\end{array}$ & 71,4 & 28,6 \\
\hline
\end{tabular}

\section{b. Penilaian Literasi Digital Peserta Didik Siklus II}

1) Rubrik Penilaian Literasi Digital Peserta Didik Siklus II

Tabel 8. Hasil Penilaian Literasi Digital Peserta Didik Siklus II

\begin{tabular}{|c|l|c|c|c|c|c|c|c|}
\hline \multirow{2}{*}{$\begin{array}{c}\text { N } \\
\mathbf{o}\end{array}$} & \multicolumn{1}{|c|}{ Kelompok } & \multicolumn{6}{|c|}{ Aspek yang dinilai } & Total \\
akses & $\begin{array}{c}\text { Meran } \\
\text { gkai }\end{array}$ & $\begin{array}{c}\text { Mema } \\
\text { hami }\end{array}$ & $\begin{array}{c}\text { Menyebarkan } \\
\text { Informasi }\end{array}$ & Nilai & $\begin{array}{c}\text { Krit } \\
\text { eria }\end{array}$ \\
\hline 1 & $\begin{array}{l}\text { Kelompok1(Perang } \\
\text { Aceh) }\end{array}$ & 3 & 4 & 3 & 4 & 14 & 88 & SB \\
\hline 2 & $\begin{array}{l}\text { Kelompok2(Perang } \\
\text { maluku) }\end{array}$ & 3 & 4 & 3 & 4 & 14 & 88 & SB \\
\hline 3 & $\begin{array}{l}\text { Kelompok3(Perang } \\
\text { Padri 1) }\end{array}$ & 4 & 4 & 3 & 4 & 15 & 94 & SB \\
\hline 4 & $\begin{array}{l}\text { Kelompok4(Perang } \\
\text { Diponegoro) }\end{array}$ & 1 & 3 & 3 & 2 & 9 & 56 & CB \\
\hline 5 & $\begin{array}{l}\text { Kelompok5(Perang } \\
\text { Jagaraga) }\end{array}$ & 2 & 2 & 1 & 3 & 8 & 50 & CB \\
\hline
\end{tabular}




\begin{tabular}{|l|c|c|c|c|}
\hline Jumlah & 13 & 17 & 13 & 17 \\
\hline Nilai & 65 & 85 & 65 & 85 \\
\hline Kriteria & B & SB & B & SB \\
\hline
\end{tabular}

\section{2) Hasil Penilaian Diri Peserta Didik Siklus II}

Bisa dilihat pada table penilaian diri kreativitas dan literasi digital peserta didik siklus II.

Diketahui bahwa kreativitas peserta didik setelah tindakan rata-rata 72,5 sedangkan rata-rata nilai literasi digital peserta didik sebesar 62,5. Rata-rata kreativitas dan literasi peserta didik melalui rubrik penilaian dapat dilihat pada tabel dan diagram berikut :

Tabel 9. Rekap Penilaian Kreativitas Film Pendek Sejarah Siklus I

\begin{tabular}{|c|l|c|c|}
\hline \multirow{2}{*}{ No } & \multirow{2}{*}{ Aspek yang dinilai } & \multicolumn{2}{|c|}{ Siklus I } \\
\cline { 3 - 4 } & Skor & Kriteria \\
\hline 1 & Orisinal (Orisinalitas) & 75 & Kreatif \\
\hline 2 & Luwes (Flexibility) & 60 & Cukup Kreatif \\
\hline 3 & Lancar (Fluency) & 80 & Kreatif \\
\hline 4 & Rinci (Elaboration) & 75 & Kreatif \\
\hline \multicolumn{2}{|l}{ Rata-rata } & $\mathbf{7 2 , 5}$ & Kreatif \\
\hline
\end{tabular}

Tabel 10. Rekap Penilaian Literasi Digital Peserta Didik Siklus I

\begin{tabular}{|c|l|c|c|}
\hline \multirow{2}{*}{ No } & \multicolumn{2}{|c|}{ Aspek yang dinilai } & \multicolumn{2}{|c|}{ Siklus I } \\
\cline { 3 - 4 } & & Skor & Kriteria \\
\hline 1 & Mengakses & 55 & Cukup Baik \\
\hline 2 & Merangkai & 85 & Sangat Baik \\
\hline 3 & Memahami & 45 & Cukup Baik \\
\hline 4 & Menyebarkan Informasi & 65 & Baik \\
\hline \multicolumn{2}{|c|}{ Rata-rata } & $\mathbf{6 2 , 5}$ & Baik \\
\hline
\end{tabular}

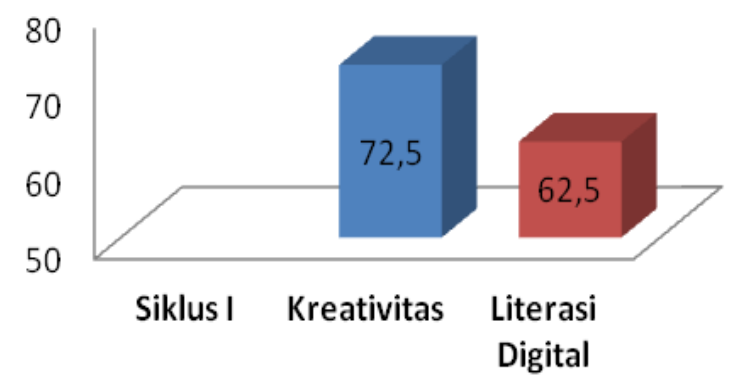

Gambar 1. Diagram Penilaian Kreativitas dan Literasi Digital Peserta Didik Siklus I 
Setelah dilakukan observasi dan penilaian diri peserta didik terdapat beberapa permasalahan antara lain :

1. Peserta didik kesulitan dalam mencari dan mendapatkan referensi yang relevan untuk digunakan sebagai acuan dalam menentukan alur cerita sejarah dalam pembuatan film pendek.

2. Dampak dari Poin 1 atau minimnya referensi menyebabkan pesan atau informasi film pendek sulit dipahami.

3. Beberapa kelompok kesulitan dalam mengakses internet untuk mengupload karya film pendek mereka.

4. Kurangnya waktu yang disediakan dalam penugasan (resitasi) pembuatan film pendek sejarah.

Berdasarkan permasalahan di atas, maka refleksi yang dilakukan dalam usaha perbaikan atau solusi untuk siklus selanjutnya adalah :

1. Pendidik mencarikan alternatif buku atau referensi relevan.

2. Dengan alternatif buku atau referensi relevan dari pendidik diharapkan peserta didik mampu membuat alur cerita yang sesuai sehingga pesan atau informasi film pendek sejarah mudah dipahami.

3. Pendidik menyarankan kepada kelompok atau peserta didik yang kesulitan akses internet untuk memanfaatkan fasilitas internet sekolah.

4. Pendidik bersama peserta didik menyepakati penambahan waktu 1 minggu untuk menyempurnakan resitasi pembuatan film pendek sejarah.

Setelah dilakukan tindakan perbaikan atau solusi pada siklus II dapat diketahui rata-rata nilai kreativitas dan literasi digital sebagai berikut :

Tabel 11. Rekap Penilaian Kreativitas Film Pendek Sejarah Siklus II

\begin{tabular}{|c|l|c|c|}
\hline No & Aspek yang dinilai & Nilai & Kriteria \\
\hline 1 & Orisinal (Orisinalitas) & 85 & Sangat Kreatif \\
\hline 2 & Luwes (Flexibility) & 75 & Kreatif \\
\hline 3 & Lancar (Fluency) & 85 & Sangat Kreatif \\
\hline 4 & Rinci (Elaboration) & 80 & Kreatif \\
\hline Rata-rata & $\mathbf{8 1 , 3}$ & Sangat Kreatif & \\
\hline
\end{tabular}


Tabel 12. Rekap Penilaian Literasi Digital Peserta Didik Siklus II

\begin{tabular}{|c|l|c|c|}
\hline No & \multicolumn{1}{|c|}{ Aspek yang dinilai } & Nilai & Baik \\
\hline 1 & Mengakses & 65 & Baik \\
\hline 2 & Merangkai & 85 & Sangat Baik \\
\hline 3 & Memahami & 65 & Baik \\
\hline 4 & Menyebarkan Informasi & 85 & Baik \\
\hline Rata-rata & $\mathbf{7 5 , 0}$ & Baik & \\
\hline
\end{tabular}

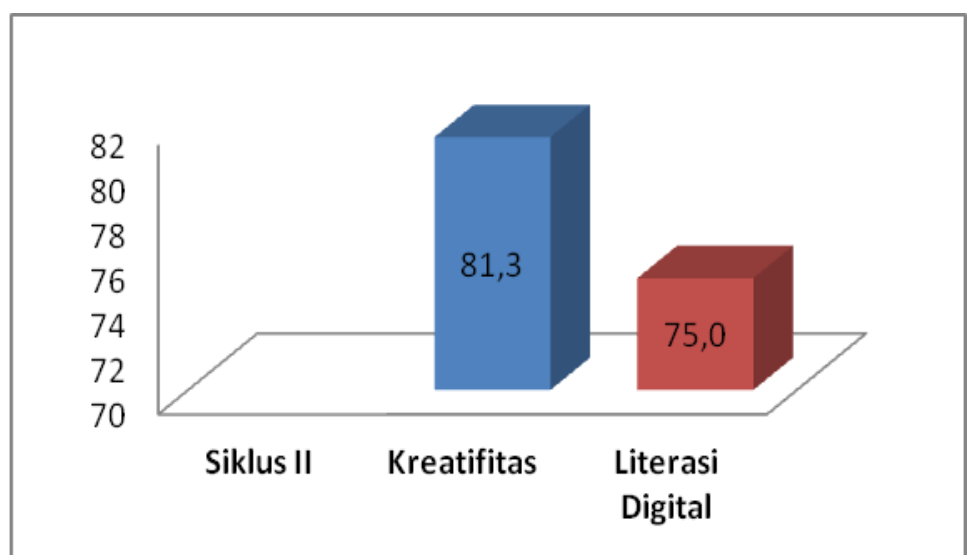

Gambar 2. Diagram Penilaian Kreativitas dan Literasi Digital Peserta Didik Siklus II

Dari Tabel dan diagram diatas diketahui terjadi peningkatan ratarata kreativitas peserta didik pada siklus I sebesar 72,5 menjadi 81,3 pada siklus II. Sedangkan literasi digital meningkat dari 62,5 pada siklus I menjadi 75,0 pada siklus II.

\section{Penutup}

Berdasarkan analisis hasil penelitian di atas, dapat disimpulkan bahwa metode resitasi dalam pembuatan film pendek sejarah mampu meningkatkan kreativitas peserta didik. Pada siklus I menunjukkan ratarata nilai kreativitas peserta didik 72,5 . Pada siklus II rata-rata nilai kreativitas peserta didik meningkat menjadi 81,3. Metode resitasi dalam pembuatan film pendek sejarah mampu meningkatkan literasi digital peserta didik. Hasil penelitian pada siklus I menunjukkan rata-rata nilai literasi digital peserta didik meningkat dari 62,5 menjadi 75,0 pada siklus II. Kreatifitas dan literasi digital peserta didik meningkat dengan adanya 
resitasi dalam pembuatan film pendek tentang sejarah. Peserta didik tertarik untuk mengeksplorasi kreatifitasnya. Dan untuk keperluan itu secara tidak langsung, mereka mengasah kemampuannya dalam hal penggunaan sarana TIK dan penciptaan konten digital untuk pembelajaran.

Beberapa saran terkait hasil penelitian ini bagi peserta didik diharapkan peserta didik mampu terasah kreativitas dan literasi digitalnya sehingga akan muncul sineas muda sejak dini dalam dunia perfilman tanah air. Pendidik dapat menerapkan metode pembelajaran ini di sekolahnya sebagai salah satu alternatif pembelajaran inovatif untuk meningkatkan kreativitas dan literasi digital peserta didik, khususnya dalam pembelajaran IPS. Sekolah diharapkan dapat memfasilitasi tumbuhnya kreatifitas dalam meningkatkan kualitas pembelajaran.

\section{Daftar Referensi}

Anonim. 2018. Karakteristik Pendidik dan Peserta didik Abad 21. Hand Out Modul PPG Dalam Jabatan

Arikunto., \& Suharsimi dkk. 2007. Penulisan Tindakan Kelas. Jakarta : Bumi Aksara

Bawden, D. 2001. Information and Digital Literacies: A Review of Concepts. in Journal of Documentation, 57(2), 218-259

Latief, Rusman., \& Utud, Yusiatie. 2013. Kamus Pintar Broadcasting. Bandung: Yrama Widia

Nana, Syaodih Sukmadinata. 2004. Landasan Psikologi Proses Pendidikan. Bandung: Remaja Rosdakarya

Slameto. 1991. Proses Belajar Mengajar Dalam Sistem Kredit Semester (SKS). Jakarta : Bumi Aksara 
Vol. 4, No. 3, November 2020 